\author{
Doc. dr. sc. Mijo Galiot ${ }^{1}$ \\ sudac Općinskog suda u Splitu \\ Vanesa Brizić Bahun, dipl. iur. ${ }^{2}$ \\ sutkinja Općinskog građanskog suda u Zagrebu
}

\title{
ODLUKE SUDA U POSTUPKU POVODOM IMOVINSKOPRAVNOG ZAHTJEVA
}

\author{
UDK: $343 / 344$ \\ DOI: $10.31141 /$ zrpfs.2021.58.142.1141 \\ Pregledni rad \\ Primljeno: 15. 05. 2021.
}

Autori u radu daju pregled i analizu pozitivnih kaznenopravnih odredbi koje reguliraju postupanje suda kada u vezi s imovinskopravnim zahtjevom odlučuje o procesnim ili meritornim pitanjima. Specifičnost je instituta imovinskopravnog zahtjeva to da se radi o mješavini kaznenog i građanskog prava i postupka što upućuje da bi sud u kaznenom postupku odlučujući o njemu trebao primjenjivati ne samo odredbe kaznenog procesnog prava već na odgovarajući način i parničnog procesnog prava. Stoga se u radu analizira sadrži li kazneno zakonodavstvo Republike Hrvatske odgovarajuću regulaciju svih procesnih pitanja o kojima treba odučiti tijekom vođenja postupka uz prijedlog mogućih rješenja. Nadalje se ukazuje na ograničenu mogućnost odlučivanja o imovinskopravnom zahtjevu u smislu da ga sud u kaznenom postupku ni u kom slučaju nije ovlašten odbiti, a isto tako ni usvojiti ako ne donese osuđujuću presudu. Također autori obrađuju neka specifična pitanja koja se u odnosu na imovinskopravni zahtjev mogu pojaviti tijekom postupka ovrhe čije je poznavanje potrebno kako bi se u praksi osigurala učinkovita provedba odluka koje donosi sud u kaznenom postupku.

Ključne riječi: oštećenik, imovinskopravni zahtjev, adhezijski postupak, odluke, ovrha

\section{UVOD}

U suvremenoj državi pružanje zaštite subjektivnim građanskim pravima, koja se definiraju kao skup ovlaštenja koja pravnom subjektu u određenom građanskopravnom odnosu priznaju norme objektivnog građanskog prava, ${ }^{3}$ predstavlja zakonom uređenu društvenu funkciju. ${ }^{4}$ Opća, redovna i osnovna

1 Doc. dr. sc. Mijo Galiot, e-mail: galiot1305@gmail.com

2 Vanesa Brizić Bahun, dipl. iur., e-mail: vanesa.brizic@ gmail.com

3 Mladen Vedriš, Petar Klarić, Građansko pravo, Opći dio, stvarno pravo, obvezno i nasljedno pravo (Zagreb: Narodne novine, 2003.), 65.

${ }^{4}$ Siniša Triva, Mihajlo Dika, Građansko parnično procesno pravo (Zagreb: Narodne novine, 2004.), 10. 
metoda zaštite ugroženih ili povrijeđenih subjektivnih prava koju država pruža kroz pravosudnu organizaciju jest građanski parnični postupak. ${ }^{5}$

Međutim, kako do povrede subjektivnog prava može doći i počinjenjem kaznenog djela, to isti događaj može biti predmet raspravljanja u kaznenom i građanskom (parničnom) postupku. Stoga se pravna zaštita subjektivnih prava koja su povrijeđena ili ugrožena počinjenjem kaznenog djela može pružati i u kaznenom postupku kroz institut imovinskopravnog zahtjeva.

Iako odredbe koje uređuju imovinskopravni zahtjev nisu brojne, njihova analiza ukazuje na to da se radi o složenom institutu za čije potpuno razumijevanje i pravilnu primjenu nije dovoljno samo poznavanje navedenih odredbi jer je domašaj instituta daleko širi od navedenog i zahvaća u brojna teorijska i praktična pitanja.

Specifičnost je instituta u tome da se radi o mješavini kaznenog i građanskog prava i postupka što upućuje da bi sud u kaznenom postupku odlučujući o imovinskopravnom zahtjevu trebao primjenjivati ne samo odredbe kaznenog procesnog prava već na odgovarajući način i parničnog procesnog prava. ${ }^{6}$

Temeljni cilj autora bio je dati pregled i analizu pozitivnih kaznenopravnih odredbi koje reguliraju postupanje suda u vezi s imovinskopravnim zahtjevom te ocijeniti kako se navedena specifičnost instituta ogleda u praksi i koje se i uz primjenu kojih odredaba, donose odluke povodom imovinskopravnog zahtjeva (procesne i meritorne), da li takvo postupanje na najbolji način omogućuje zaštitu oštećenikovih prava i postiže li svrhu koja je samom institutu namijenjena.

Naime, donošenje odluke nije samo sebi svrha već je smisao kako popraviti povrijeđeno pravo, a to nas dovodi do pitanja kako se odluka o imovinskopravnom zahtjevu može prisilno ostvariti (ovršiti) kojim pitanjem se ovaj rad također u određenoj mjeri bavi u odnosu na neka specifična pitanja koja su značajna upravo za imovinskopravni zahtjev.

Unutar provedene analize izvodi se usporedba s odgovarajućim institutima i odredbama koje uređuju građanski parnični postupak te se uz osvrt na recentnu sudsku praksu daju prijedlozi mogućih normativnih rješenja kojima bi se navedeni postupak sistematičnije uredio, što bi dovelo i do kvalitetnijeg i efikasnijeg rješavanja predmeta u praksi.

5 Triva, Dika, Građansko parnično procesno pravo, 3.

6 Eduard Kunštek u: Berislav Pavišić i suradnici, Kazneno postupovno pravo, 3. Izdanje (Rijeka: Pravni fakultet Sveučilišta u Rijeci, 2010.), 167, smatra kako bi postupak morao biti dosljedan čl. 1. ZPP-a „parnica u okviru kaznenog postupka“ koja bi se u potpunosti vodila na način i u postupku određenom ZPP-om. Međutim, kako se o tom zahtjevu raspravlja u okviru kaznenog postupka, dolazi do bitnih odstupanja od odredaba ZPP-a i postupak se vodi prema odredbama ZKP-a. 


\section{OPĆENITO O ADHEZIJSKOM POSTUKU U POVODU POSTAVLJENOG IMOVINSKOPRAVNOG ZAHTJEVA}

Postupak povodom imovinskopravnog zahtjeva predstavlja u svojoj biti građansku parnicu koja je pridružena kaznenom postupku (adhezijski postupak) te se definira kao sporedni predmet ${ }^{7}$ građanskopravne naravi u okviru kaznenog postupka. Prema pravnoj naravi to je građanski predmet u odnosu na koji se postupa prema procesnim pravilima kaznenog postupka, a supsidijarno za njega vrijede pravila građanskog procesnog prava. ${ }^{8}$

To nadalje znači da postavljanje imovinskopravnog zahtjeva u kaznenom postupku omogućuje da se osim odlučivanja o sumnji ili optužbi protiv okrivljenika zbog počinjenog kaznenog djela, u kaznenom postupku odlučuje i o nekom pravu ili obvezi građanske prirode koja mora biti u vezi s glavnim predmetom. ${ }^{9}$ Oštećenik svakako može svoj zahtjev ostvarivati i u posebnom parničnom postupku, međutim, omogućavanje učinkovitog ostvarivanja njegovih prava već u kaznenom postupku korisno je i za pravosuđe, a naravno i za njega ${ }^{10}$

Vođenje takvog postupka u skladu je s načelom ekonomičnosti postupka, ${ }^{11}$ a dopušteno je u granicama koje se ne protive pravilima o litispendenciji i res iudicati (presuđenoj stvari). ${ }^{12}$ Ekonomičnost vođenja takvog postupka ogleda se ne samo u izbjegavanju dvostrukog suđenja veći u činjenici da je za oštećenika brzi ekonomičan način da kazneni sud, kad već utvrđuje pravno relevantne činjenice kaznenog djela i odlučuje o krivnji, istodobno odluči i o građanskopravnoj odgovornosti te najčešće i šteti koja potječe iz kaznenog djela. ${ }^{13}$

7 U hrvatskom pravu postoje tri sporedna predmeta kaznenog postupka: a) imovinskopravni zahtjevi, b) prejudicijalna pitanja i c) troškovi kaznenog postupka. - V. više Kunštek u Pavišić, Kazneno postupovno pravo, 75 .

8 Kunštek u Pavišić, Kazneno postupovno pravo, 76.

9 Kunštek u Pavišić, Kazneno postupovno pravo, 75.

$10 \mathrm{Kad}$ su u pitanju građanskopravne norme, država nije toliko zainteresirana hoće li one biti poštovane, pa pokretanje postupka ovisi isključivo o volji osobe čije je subjektivno pravo povrijeđeno ili ugroženo. Jedino je i dalje zainteresirana da ona odlučuje o tome je li subjektivno pravo povrijeđeno ili ugroženo, odnosno da o toj okolnosti odluku donese i zaštitu pruži njezin sud. - V. Eduard Kunštek, „Actio civilis u kaznenom postupku - prijedlog novele“, Zbornik radova, Deset godina rada Zavoda za kaznene znanosti Mošćenice Pravnog fakulteta Sveučilišta u Rijeci (Rijeka: Pravni fakultet Sveučilišta u Rijeci, 2008.), 207, https://www.yumpu.com/it/document/read/18209553/decennium-moztanicense.

11 Načelo ekonomičnosti izrijekom je sadržano u odredbi čl. 10. Zakona o parničnom postupku, Narodne novine broj 53/91, 91/92, 112/99, 88/01, 117/03, 88/05, 02/07, 84/08, 96/08, 123/08, 57/11, 148/11 (pročišćeni tekst), 25/13, 89/14 i 70/19 (dalje u tekstu: ZPP) koja određuje da se postupak mora provesti bez odugovlačenja, u razumnom roku i sa što manje troškova.

12 Dok parnica teče, ne može se voditi adhezijski postupak o istom zahtjevu i obratno, a o zahtjevu o kojem je pravomoćno odlučeno ne može se ponovno meritorno raspravljati i odlučivati. - Više u Triva, Dika, Građansko parnično procesno pravo, 90.

13 Davor Krapac, Kazneno procesno pravo, Prva knjiga: Institucije (Zagreb: Narodne novine, 2015.), 259. 
Institut imovinskopravnog zahtjeva normiran je odredbama XI. glave ZKP/08 ${ }^{14}$ i to člancima 153. do 162. Prema odredbi čl. 153. ZKP/08 imovinskopravni zahtjev koji je nastao zbog počinjenja kaznenog djela raspravit će se na prijedlog oštećenika u kaznenom postupku, ako se time ne bi znatno odugovlačio taj postupak.

Kako se radi o imovinskopravnom zahtjevu koji je u vezi s određenim kaznenim djelom povodom kojeg se vodi kazneni postupak i o kojem će se stoga odlučivati unutar tog postupka, primjenjivat će se primarno odredbe kaznenog procesnog zakonodavstva. Međutim, materijalnopravne pretpostavke za donošenje odluke o imovinskopravnom zahtjevu sadržane su u propisima koji uređuju materiju građanskog prava ${ }^{15}$ pa će sud u kaznenom postupku ocjenjivati osnovanost postavljenog imovinskopravnog zahtjeva primjenom propisa građanskog prava na činjenično stanje koje je utvrdio u kaznenom postupku. ${ }^{16}$

Iz opće odredbe koju sadržava upravo citirani čl. 153. ZKP/08 proizlaze ne samo osnovne pretpostavke koje se moraju ispuniti da bi sud odlučivao o imovinskopravnom zahtjevu, već određuje i aktivnu legitimaciju za njegovo podnošenje (dok se presumira da je pasivno legitimiran okrivljenik). Ujedno je određeno da se imovinskopravni zahtjev može odnositi na svaki zahtjev koji se može podnijeti u parnici (čl. 153. st. 2. ZKP/08) time da isti mora biti u vezi s počinjenim kaznenim djelom, dakle, da je nastao zbog počinjenja kaznenog djela. Najveći broj imovinskopravnih zahtjeva ipak će se odnositi na naknadu štete ili povrat stvari (kondemnatorne naravi), ali moguće je postavljanje i konstitutivnih (poništenje pravnog posla) i deklaratornih zahtjeva (utvrđenje ništetnosti pravnog posla) uz koje će, naravno, najčešće biti istaknuti i odgovarajući kondemnatorni zahtjevi na isplatu odnosno naknadu štete.

\section{PROCESNE ODLUKE SUDA TIJEKOM POSTUPKA O IMOVINSKOPRAVNOM ZAHTJEVU}

Kada se radi o postupku u povodu imovinskopravnog zahtjeva, u njemu se postupa prema procesnim pravilima kaznenog postupka, ali supsidijarno za njega vrijede pravila građanskog procesnog prava. ${ }^{17} \mathrm{Za}$ sud $\mathrm{u}$ kaznenom postupku to znači da će raspravljajući o imovinskopravnom zahtjevu morati u određenoj mjeri primjenjivati i procesna pravila Zakona o parničnom postupku, osobito ona koja se odnose na načelo dispozitivnosti (čl. 2. i 3. ZPP-a). Naime, kazneni sud vodi i

14 Zakon o kaznenom postupku, Narodne novine broj 152/08, 76/09, 80/11, 121/11, 143/12, 56/13, 145/13, 152/14, 70/17, 126/19 (dalje u tekstu: ZKP/08).

$15 \mathrm{Za}$ obvezne odnose to je prvenstveno Zakon o obveznim odnosima, Narodne novine broj 35/05, 41/08, 125/11, 78/15, 29/18 (dalje u tekstu: ZOO), za stvarna prava Zakon o vlasništvu i drugim stvarnim pravima, Narodne novine broj 91/96, 68/98, 137/99, 22/00, 73/00, 129/00, 114/01, 79/06, 141/06, 146/08, 38/09, 153/09, 143/12, 152/14 (dalje u tekstu: ZV) i dr.

16 O tome vidi više Eduard Kunštek, „Imovinskopravni zahtjevi“ u Berislav Pavišić, Komentar Zakona o kaznenom postupku, 5. izdanje (Rijeka: Žagar, 2005.), 167.

17 Vidi bilješku br. 4. 
adhezijski postupak po pravilima kaznenog postupka, ali se tijekom vođenja tog postupka pojavljuju određena pitanja procesne naravi za koja kazneni postupak nema u svakom slučaju određenu zakonsku regulaciju.

Kada sud u parničnom postupku poduzima određene radnje, one imaju jedan zajednički osnovni zadatak, a to je da dovedu do odluke o osnovanosti ili neosnovanosti zahtjeva za pružanje određene pravne zaštite. Sudske su odluke parnične radnje kojima sud izražava svoju volju o pitanjima koja se pojavljuju tijekom parnice. ${ }^{18}$ Svoj stav o određenim procesnim pitanjima sud može očitovati izrijekom, u obliku posebne odluke, ili prešutno, poduzimanjem radnji koje podrazumijevaju zauzimanje takva stava koji nije izrekao. ${ }^{19}$

Sud u kaznenom postupku odluke, osim u obliku presude, donosi u obliku rješenja i naloga. Najčešće su to odluke kojima se odlučuje o pojedinim pitanjima poduzimanja procesnih radnji, započinjanja ili zaključenja pojedinih procesnih stadija i dr., a djelovanje im je usmjereno isključivo na određenu procesnu situaciju. ${ }^{20}$

Nakon što zaprimi prijedlog za ostvarivanje imovinskopravnog zahtjeva u kaznenom postupku, sud koji vodi postupak ${ }^{21}$ po logici stvari trebao bi ispitati je li isti uredan i sadrži li sve što je potrebno da bi se po njemu moglo postupati.

U prijedlogu je oštećenik dužan određeno naznačiti svoj zahtjev i podnijeti dokaze (čl. 155. st. 3. ZKP/08). Navedeno je potrebno kako bi sud mogao ispitati okolnosti koje su važne za utvrđivanje imovinskopravnog zahtjeva. ${ }^{22}$ Određeno naznačiti zahtjev znači da zahtjev mora biti određen u pogledu glavne stvari i sporednih traženja. ${ }^{23}$

S obzirom na to da prijedlog oštećenika zamjenjuje tužbu, isti bi trebao imati sve elemente koje mora imati i tužba počevši od već navedenog određenog zahtjeva u pogledu glavne stvari i sporednih traženja te dokaza kojima se utvrđuju činjenice na kojima se temelji zahtjev, ali i druge podatke koje mora imati svaki podnesak (čl. 186. st. 1. ZPP-a). Ako je oštećenik podnio prijedlog za ostvarivanje imovinskopravnog zahtjeva, koji ne sadrži sve što je potrebno da bi se po njemu moglo postupiti, sud može (iako to nije izričito navedeno) na odgovarajući način primijeniti odredbu čl.

18 Triva, Dika, Građansko parnično procesno pravo, 351.

19 Dika, Građansko parnično pravo, Parnične radnje, V knjiga (Zagreb: Narodne novine, 2008.), 149.

20 Krapac, Kazneno procesno pravo, 292.

21 Prijedlog se može podnijeti i tijelu kojem se podnosi kaznena prijava - čl. 155. st. 1. ZKP/08.

22 Vrhovni sud Republike Hrvatske, Kž 483/2020 od 21. rujna 2020.

23 U tom se smislu u odluci Županijskog suda u Varaždinu, Gž 372/2007 od 13. lipnja 2007. navodi: „Postavljanje imovinskopravnog zahtjeva u kaznenom postupku ima se smatrati podnošenjem tužbe pa kako je imovinskopravni zahtjev u kaznenom postupku postavljen po tužitelju potpuno neodređeno „stavljanjem zahtjeva za naknadu štete i to prema zakonu“ ... nedvojbeno se može zaključiti da tužitelj u kaznenom postupku do dana 09.07.2001. nije postavio imovinskopravni zahtjev za pretrpljene fizičke bolove i strah jer je zahtjev potpuno neodređen i nerazumljiv“. 
78. ZKP $/ 08^{24}$ i pozvati oštećenika da podnesak ispravi, odnosno dopuni, a ako on to ne učini u određenom roku, podnesak, dakle, prijedlog oštećenika, odbaciti.

Međutim, ZKP/08 ne sadrži odgovarajuću odredbu kojom bi se propisalo postupanje suda u situaciji kada se kao oštećenik pojavi osoba koja ne može biti stranka u postupku ${ }^{25}$ iako je u parničnom postupku sud na nedostatak stranačke sposobnosti dužan paziti po službenoj dužnosti u tijeku cijelog postupka i uočene nedostatke otklanjati, odnosno u slučaju nemogućnosti otklanjanja, odbaciti tužbu (čl. 82. i 83. ZPP-a). Budući da ZKP/08 kada uređuje postupanje suda u postupku povodom imovinskopravnog zahtjeva (iako se u osnovi radi o parničnom postupku koji se vodi u okviru kaznenog postupka) ne upućuje na odgovarajuću primjenu odredaba ZPP-a, potrebno je utvrditi može li neka postojeća odredba ZKP/08 razriješiti navedenu problematiku.

Analizom navedenih odredbi zaključuje se da je jedina odredba koja bi u takvoj situaciji eventualno mogla biti primijenjena, odredba čl. 46. ZKP/08 kojom je određeno da se žrtva i pravna osoba na čiju je štetu kazneno djelo počinjeno imaju pravo prijaviti kao oštećenik do podizanja optužnice, policiji ili državnom odvjetništvu, a do završetka rasprave sudu. Prijavu koja je nepravodobna ili podnesena od neovlaštene osobe, tijelo koje vodi postupak odbacit će rješenjem. Stoga bi sud na isti način mogao postupiti i kada se radi o prijedlogu za podnošenje imovinskopravnog zahtjeva jer se također radi o prijedlogu koji je ovlašten podnijeti samo oštećenik (koji mora imati i stranačku sposobnost) i to u određenim rokovima.

Prijedlog za ostvarivanje imovinskopravnog zahtjeva može se podnijeti najkasnije do završetka dokaznog postupka pred prvostupanjskim sudom (čl. 155. st. 3. ZKP/08). U odnosu na ZKP/ $97^{26}$ radi se o izmjeni jer se ranije prijedlog mogao staviti sve do završetka glavne rasprave pred prvostupanjskim sudom. Međutim, tada bi sud bio dužan ponovno „otvoriti“ dokazni postupak s obzirom na njegovu dužnost da o činjenicama iznesenima u prijedlogu ispita okrivljenika (čl. 131. st. 1. ZKP/97). To je, naravno, dovodilo do nepotrebnog odugovlačenja kaznenog postupka te je sadašnje zakonsko ograničenje mogućnosti podnošenja prijedloga do završetka dokaznog postupka, znatno bolje rješenje.

Kao što smo naveli, ZKP/08 ne propisuje izrijekom dužnost (a ni ovlaštenje) suda u kaznenom postupku u slučaju nepostojanja procesnih pretpostavki za odlučivanje o postavljenom imovinskopravnom zahtjevu, taj prijedlog odbaciti, iako bi to u izloženim slučajevima bilo potrebno. Smatramo kako ne bi bilo u interesu pravne

$24 \mathrm{U}$ čl. 78. ZKP/08 propisuje se na koji način sud u kaznenom postupku postupa s nerazumljivim i nepotpunim podnescima (privatne tužbe, optužnice, prijedlozi za progon, pravni lijekovi te druge izjave i priopćenja). Iako prijedlog za ostvarivanje imovinskopravnog zahtjeva nije izrijekom naveden $u$ spomenutoj odredbi, smatramo da se ista može i mora primijeniti i u slučaju nerazumljivih ili nepotpunih prijedloga za ostvarivanje imovinskopravnog zahtjeva jer je i takav prijedlog podnesak. Odgovarajuća odredba o postupanju s takvim podnescima (i tužbama) u parničnom postupku sadržana je u odredbi čl. 109. ZPP-a.

25 Stranka u postupku može biti samo fizička ili pravna osoba (čl. 77. ZPP-a).

26 Zakon o kaznenom postupku, Narodne novine broj: 110/97, 27/98, 112/99, 58/02, 143/02, 62/03, 115/06, (dalje u tekstu: ZKP/97). 
sigurnosti postavljeni prijedlog samo zanemariti. Prvenstveno stoga što je sud dužan odlučiti o svakom zahtjevu stranke, ${ }^{27}$ a uz to je korisno ta pitanja raščistiti što prije kako bi oštećenik pravovremeno bio upoznat sa svojom pravnom pozicijom. ${ }^{28}$

Sud u kaznenom postupku također treba voditi računa da je raspravljanje o imovinskopravnom zahtjevu u kaznenom postupku ograničeno pravilima o litispendenciji i presuđenoj stvari što znači da ne može raspravljati o imovinskopravnom zahtjevu ako se o istom već vodi parnični postupak ili je o njemu već pravomoćno odlučeno u parnici. ${ }^{29}$ Zakonom nije definirano kakvu će odluku u tom slučaju donijeti kazneni sud pa proizlazi da bi i u tom slučaju oštećenika

27 Prema čl. 2. st. 2. ZPP-a sud ne može odbiti odlučivati o zahtjevu za koji je nadležan.

28 V. Triva, Dika, Građansko parnično procesno pravo, 30.

29 Ustavni sud Republike Hrvatske u Odluci U-III-2509/2008. od 8. studenoga 2012. godine izričito je naveo:

„Međutim, u konkretnom je predmetu riječ o tome da je dva puta (u parničnom postupku i u adhezijskom parničnom postupku unutar kaznenog postupka) odlučivano o istom imovinskopravnom zahtjevu oštećenika te je oštećeniku isti dio zahtjeva dva puta pravomoćno dosuđen (odnosno, s drugim je dijelom zahtjeva upućen da pokrene parnični postupak, iako je on već proveden i u njemu je već dosuđen i taj dio zahtjeva).

Učinci osporenih presuda, koje su donesene pogrešnim tumačenjem i primjenom zakona, na položaj podnositelja ustavne tužbe stoga su takvi da protiv njega egzistiraju dvije ovršne isprave na temelju kojih oštećenik ima pravo naplatiti svoje potraživanje: jednom u cijelosti (konkretno, u parnici dosuđenih ukupno 43.248,00 eura s pripadajućim potraživanjima), te još jednom, u dijelu koji je već sadržan u prethodno navedenom iznosu (konkretno, u kaznenom postupku dosuđenih 7.158,09 eura ili 52.287,76 kuna, a valja uz to primijetiti i činjenicu da je u kaznenom postupku podnositelj B. M. bio terećen ukupno za iznos od 42.948,52 eura, dok je u parničnom postupku oštećeniku dosuđen, u odnosu na podnositelja, iznos od 43.248,00 eura - dakle, čak i nešto veći iznos glavnog potraživanja, kao i kamate).

Iako, dakle, Ustavni sud smatra da članak 31. stavak 2. Ustava, na kojeg se podnositelj ustavne tužbe izrijekom pozvao, nije mjerodavan za ocjenu o povredi ustavnih prava u konkretnom slučaju, nedvojbeno je da Ustav osigurava zaštitu od povreda postupovnih jamstava pravičnog suđenja u sudskim postupcima (među kojima i načela ne bis in idem) putem jamstava iz članka 29. stavka 1. Ta su jamstva ujedno temeljna, opća jamstva pravne sigurnosti i vladavine prava.

Ustavni sud je stoga ocijenio da podnositelju nije povrijeđeno ustavno pravo iz članka 31. stavka 2. Ustava, ali da mu je osporenim presudama, u dijelovima koji se odnose na primjenu članka 132. stavka 2. ZKP-a, a koji su izrekom ove odluke i ukinuti, povrijeđeno pravo na pravično suđenje, koje je člankom 29. stavkom 1. Ustava zajamčeno (i) u naprijed navedenom smislu.

Vraćajući se ponovo na učinke osporenih presuda na položaj podnositelja ustavne tužbe, Ustavni sud primjećuje da podnositelj ustavne tužbe ne "trpi” samo nepravičnost (djelomično) nezakonite sudske odluke na apstraktnoj razini. Već je, naime, navedeno da protiv podnositelja, kao posljedica postupanja sudova, egzistiraju dvije ovršne isprave na temelju kojih oštećenik ima pravo naplatiti svoje potraživanje: jednom u cijelosti te još jednom, u dijelu koji je već sadržan u cjelokupnom iznosu. Učinci osporenih presuda odražavaju se, prema tome, izravno na imovini podnositelja." 
Doc. dr. sc. Mijo Galiot i Vanesa Brizić Bahun, dipl. iur.: Odluke suda u postupku povodom... Zbornik radova Pravnog fakulteta u Splitu, god. 58, 4/2021, str. 1141-1163

bio dužan uputiti u parnicu ${ }^{30}$ što nema nikakvog smisla jer bi zahtjev, analogno pravilima ZPP-a (čl. 194. i 333. ZPP-a), trebao odbaciti. ${ }^{31}$

Oštećenik je ovlašten od svog imovinskopravnog zahtjeva u svakom trenutku odustati. U tom slučaju više ga ne može ponovno staviti u kaznenom postupku i tada mu jedino preostaje mogućnost vođenja parnice. Odustanak od prijedloga najviše sliči povlačenju tužbe u parničnom postupku iako za njezin procesnopravni učinak nije potreban pristanak okrivljenika. ${ }^{32}$

ZKP/08 u odredbama koje reguliraju postupanje povodom imovinskopravnog zahtjeva ne propisuje dužnost (ni mogućnost) suda da odustanak oštećenika utvrdi nekom odlukom dok se u parničnom postupku o povlačenju tužbe donosi rešenje deklaratorne naravi kojim se utvrđuje da je tužba povučena.

S druge strane, u odredbi čl. 557.f. st. 2. ZKP/08 propisuje da ce sud, ako oštećenik odustane od imovinskopravnog zahtjeva ili privremene mjere određene radi osiguranja imovinskopravnog zahtjeva, prije donošenja odluke o tome obavijestiti državnog odvjetnika i odrediti mu primjereni rok u kojem može predložiti privremenu mjeru radi osiguranja oduzimanja imovinske koristi. Navedeno bi upućivalo da bi sud i o odustanku od imovinskopravnog zahtjeva ipak trebao donijeti odluku. ${ }^{33}$ Donošenje takve odluke moglo bi biti korisno i za poseban parnični postupak koji bi oštećenik pokrenuo radi ostvarivanja istog prava koje je prethodno namjeravao ostvariti imovinskopravnim zahtjevom, a u kojem bi se moglo postaviti pitanje postojanja dvostruke litispendencije jer bi se tako navedeno pitanje brže i efikasnije raspravilo.

Pitanje donošenja odgovarajućih odluka procesne naravi tijekom trajanja postupka moglo bi se postaviti i vezano uz univerzalnu i singularnu sukcesiju na strani oštećenika.

30 Tako je u odluci Vrhovnog suda Republike Hrvatske, Kž 85/10 od 9. travnja 2013. izričito navedeno: „Nadalje, u pravu su oba žalitelja da se o istom pravnom pitanju pred Trgovačkim sudom u Splitu vodi parnični postupak povodom tužbenog zahtjeva oštećenog trgovačkog društva S. J. u stečaju radi plaćanja iznosa od 2.963.787,84 kn koji je predmetom ovog kaznenog postupka, slijedom čega se u pogledu istog imovinskopravnog zahtjeva nije moglo odlučivati i u ovom kaznenom postupku. Ovo iz razloga, jer se odlučivanjem o imovinskopravnom zahtjevu u kaznenom postupku u stvari provodi adhezijski parnični postupak pa slijedom toga s obzirom da se za isto potraživanje oštećenog trgovačkog društva S. J. prema optuženicima vodi parnični postupak, ta okolnost sprječava odlučivanje o imovinskopravnom zahtjevu $\mathrm{u}$ adhezijskom postupku presudom u kaznenom predmetu. Prema tome, u situaciji kada je sud prvog stupnja utvrdio da je stjecanje imovinskopravne koristi u naznačenom iznosu rezultat počinjenja kaznenog djela iz čl. 337. st. 4. KZ/97 za koje su optuženici proglašeni krivim, onda je pri rješavanju pitanja imovinskopravnog zahtjeva mogao jedino uputiti oštećenika da svoj imovinskopravni zahtjev ostvaruje u parnici pri čemu bi pravomoćna presuda kaznenog suda eventualno mogla biti osnova za rješavanje parničnog postupka pred trgovačkim sudom.“

31 Upućivanjem oštećenika na pokretanje parnice u već pravomoćno presuđenoj stvari (u konkretnom slučaju dva puta za isti zahtjev) kazneni sud postupa na nesvrsishodan, iako načelno dopustiv način. Tako u Odluci Ustavnog suda Republike Hrvatske broj U-III-2509/2008. od 8. studenog 2012.

32 Kunštek u Pavišić, Komentar Zakona o kaznenom postupku, 175.

33 U povodu nastupanja pravne posljedice povlačenja tužbe trebalo bi, međutim, premda to nije izrijekom predviđeno, donijeti rješenje kojim bi se to konstatiralo, koje bi, dakle, bilo deklaratorne naravi. To bi zahtijevali razlozi pravne sigurnosti, potreba da se unese izvjesnost u odnose među strankama. Mihajlo Dika, Građansko parnično pravo, Tužba, VI. Knjiga (Zagreb: Narodne novine, 2009.), 484. 
ZPP za takve situacije precizno razrađuje postupanje suda i odluke koje donosi (čl. 212, 215. i 192. ZPP-a). ${ }^{34} \mathrm{~S}$ druge strane, ZKP/08 propisuje da ako dođe do prijenosa imovinskopravnog zahtjeva po pravilima imovinskog prava na drugu osobu nakon što je već podnesen prijedlog u kaznenom postupku, ali prije završetka dokaznog postupka, pozvat će se ta osoba da se očituje ostaje li pri prijedlogu te će se smatrati da je uredno pozvani koji se ne odazove, odustao od stavljenog prijedloga (čl. 156. st. 2. ZKP/08). Iz navedenog slijedi zaključak da se nastavak odlučivanja o imovinskopravnom zahtjevu s univerzalnim ili singularnim sukcesorom u kaznenom postupku događa bez ikakve odluke suda, jednostavnim nastavkom postupanja. ${ }^{35}$

Ova analiza pozitivne kaznenopravne regulacije izloženih procesnih pitanja ukazuje na to da se tijekom vođenja kaznenog postupka u vezi s postavljenim imovinskopravnim zahtjevom može pojaviti potreba za donošenjem određenih procesnih odluka kojima se treba riješiti niz sporednih pitanja, a postupanje suda u tim slučajevima po važećem zakonskom uređenju nije u dovoljnoj mjeri uređeno te je nedorečeno. $\mathrm{S}$ obzirom na to da se u osnovi radi o parnici unutar kaznenog postupka, odgovarajuce odredbe o postupanju suda i navedenim procesnim odlukama sadržane su u ZPP-u. Da bi u takvim situacijama trebalo na odgovarajući način primijeniti odredbe ZPP-a, ukazuje i pravna teorija u kojoj se navodi kako se parnični postupak primjenjuje i kad zakon kojim se određena građanskopravna materija uređuje o tome ništa ne određuje. ${ }^{36}$

Donošenje odgovarajućih procesnih odluka tijekom vođenja postupka potrebno je kako radi pravne sigurnosti, tako i radi uvođenja reda u odnose među strankama.

Stoga bi izložena pitanja mogla biti riješena na najjednostavniji način propisivanjem supsidijarne primjene ZPP-a u situacijama kada sud u kaznenom postupku odlučuje o pojedinim procesnim pitanjima vezanim uz imovinskopravni zahtjev, a nisu na odgovarajući način riješena odredbama ZKP/08.

\section{ODLUKE SUDA O IMOVINSKOPRAVNOM ZAHTJEVU}

U kaznenom postupku sud donosi odluke u obliku presude, rješenja i naloga. Presudom se optužba odbija ili se optuženik oslobađa optužbe ili se proglašava krivim (čl. 451. st. 1. ZKP/08). Rješenja i nalozi najčešće su odluke kojima se odlučuje o pojedinim pitanjima poduzimanja procesnih radnji, započinjanja ili zaključenja pojedinih procesnih stadija. ${ }^{37}$ Odlukom koja se donosi u kaznenom postupku raspravljaju se pitanja značajna za rješavanje kaznenog predmeta bez

34 Kod univerzalne sukcesije sud donosi odluku o prekidu i nastavku postupka, a kod singularne prihvaća subjektivnu preinaku tužbe ako tuženik na to pristane.

35 Okrivljenik nema mogućnost protiviti se singularnoj sukcesiji na strani oštećenika, kakvu bi mogućnost kao tuženik imao u parničnom postupku (čl. 192. ZPP-a).

36 Triva, Dika, Građansko parnično procesno pravo, 3.

37 V. Krapac, Kazneno procesno pravo, 292. 
obzira na to jesu li sporna ili nisu. ${ }^{38}$ Pravomoćna presuda kaznenog suda djeluje prema svima, a ne samo u odnosu na stranke na koje se neposredno odnosi, dok odluke građanskopravne naravi donesene u adhezijskom postupku djeluju samo između stranaka. ${ }^{39}$

Sud odluku o imovinskopravnom zahtjevu donosi u pravilu u presudi. O tom će zahtjevu odlučiti rješenjem samo kad obustavi kazneni postupak ili se proglasi nenadležnim, ali tada samo na način da oštećenika uputi da imovinskopravni zahtjev može ostvarivati u parnici (čl. 158. st. 2. i 3. ZKP/08). Sud može imovinskopravni zahtjev dosuditi u cijelosti ili djelomično samo u presudi kojom okrivljenika proglašava krivim..$^{40}$ I u takvoj presudi, ako ,podaci kaznenog postupka ne daju pouzdanu osnovu ni za potpuno niti za djelomično presuđenje“, oštećenika će s imovinskopravnim zahtjevom uputiti u parnicu. Kad sud donese presudu kojom se okrivljenik oslobađa optužbe ili kojom se optužba odbija ili kad rješenjem obustavi kazneni postupak, uputit će oštećenika da imovinskopravni zahtjev može ostvarivati u parnici.

Može se stoga zaključiti kako sud nije ovlašten odbiti imovinskopravni zahtjev, a niti o njemu odlučivati ako nije donio osuđujuću presudu.

Neki autori smatraju da bi sud o imovinskopravnom zahtjevu trebao odlučiti u svakom slučaju što bi bilo ekonomično rješenje, a da bi oštećenik trebao preuzeti ovaj rizik kad mu je već omogućeno da sudjeluje u postupku i postavi zahtjev. ${ }^{41}$

Analizirajući navedenu problematiku možemo se složiti da bi imajući u vidu načelo ekonomičnosti i efikasnosti sudskih postupaka te izbjegavanja dvostrukih suđenja, to moglo biti dobro rješenje koje bi svakako trebalo na odgovarajući način zakonski regulirati.

Sud tijekom trajanja kaznenog postupka izvodi dokaze radi utvrđivanja kaznene odgovornosti okrivljenika, a ujedno i radi utvrđivanja imovinskopravnog zahtjeva ako je isti postavljen. Nakon što sud u kaznenom postupku izvede sve dokaze koji mu omogućuju odlučivanje o imovinskopravnom zahtjevu pa na temelju ocjene istih utvrdi da je zahtjev oštećenika neosnovan, ne postoji opravdani razlog zbog kojeg ne bi mogao donijeti odluku kojom se taj zahtjev odbija. Sud u kaznenom postupku odlučuje o imovinskopravnom zahtjevu primjenom odgovarajućih odredbi građanskog prava te stoga, na isti način kako odlučuje o usvajanju imovinskopravnog

38 To je razlika u odnosu na građanski postupak gdje pitanja o kojima se raspravlja, jer su sporna, određuju stranke. V. Pavišić, Kazneno postupovno pravo, 154.

39 Triva, Dika, Građansko parnično procesno pravo, 89.

40 Vrhovni sud Republike Hrvatske u odluci broj Kž-260/1992 od 11. lipnja 1992: „Imovinskopravni zahtjev može se oštećeniku dosuditi u cijelosti ili djelomično samo u presudi kojom se okrivljenika oglašava krivim. Kako je okrivljenik u vrijeme izvršenja krivičnog djela bio neuračunljiv to je istraga protiv njega rješenjem istražnog suca bila obustavljena, a postupak je dalje nastavljen na temelju prijedloga javnog tužitelja za izricanje mjere sigurnosti. Prema tome, prvostepeni sud je trebao oštećenika uputiti na parnicu."

41 Tako Kunštek navodi kako oštećeni nema nikakav rizik pokretanja adhezijskog postupka, s obzirom na to da njegov potpuni ili djelomični neuspjeh neće rezultirati odbijajućom odlukom koja bi imala svojstvo res iudicata i bila procesna smetnja za vođenje naknadnog parničnog postupka. - Kunštek, „Actio civilis u kaznenom postupku - prijedlog novele“, 215. 
zahtjeva, može odlučivati i o njegovu odbijanju (u cijelosti ili djelomično) dok bi oštećenik svakako trebao imati mogućnost pobijati takvu odluku zbog svih žalbenih razloga.

Tako bi prava oštećenika bila zaštićena, kako bi se izbjegla mogućnost da se o istom zahtjevu zapravo vode dva postupka. Jednom, tijekom kaznenog postupka kao adhezijski postupak, a zatim kao poseban parnični postupak, što najmanje dovodi do dvostrukog izvođenja dokaza s obzirom na to da se dokazi koji su izvedeni tijekom kaznenog postupka u parničnom postupku moraju ponovno izvoditi jer ne postoji mogućnost njihova izravnog korištenja bez odgovarajuće suglasnosti stranaka. Također bi na taj način oštećenik brže i jeftinije ostvario zaštitu svog povrijeđenog subjektivnog prava iako bi samom postupku trebao pristupiti znatno pažljivije i aktivnije.

S obzirom na to da prema važećem zakonskom uređenju sud u kaznenom postupku ne može odbiti imovinskopravni zahtjev (ni djelomično), zaključuje se da ne bi mogao odlučivati o imovinskopravnom zahtjevu koji bi bio postavljen kao eventualna kumulacija, što znači da oštećenik svoj imovinskopravni zahtjev ne bi mogao postaviti na način da kumulira zahtjeve koji su u međusobnoj vezi ${ }^{42}$ tako da zatraži od suda da sljedeći od istaknutih zahtjeva prihvati tek ako utvrdi da onaj koji je prije njega istaknut nije osnovan (čl. 188. ZPP-a).

Jedno od otvorenih pitanja koje zahtijeva daljnju analizu jest i pitanje bi li sud u kaznenom postupku, nakon što izvede sve dokaze, mogao odlučiti o imovinskopravnom zahtjevu na način da ga usvoji i kada ne donese osuđujuću presudu. ${ }^{43}$

Ako je sud izveo sve dokaze radi utvrđivanja kaznene odgovornosti okrivljenika kao i radi utvrđivanja postavljenog imovinskopravnog zahtjeva te na temelju tako izvedenih dokaza zaključio kako ne postoji kaznena odgovornost okrivljenika, on ipak ima utvrđeno činjenično stanje koje bi mu moglo omogućiti donošenje odluke o postojanju eventualne građanske odgovornosti okrivljenika za štetu koja je kaznenim djelom počinjena oštećeniku. Građanskopravna odgovornost šira je od kaznenopravne odgovornosti, što znači da kod iste štetnik može biti odgovoran za štetu po samom načelu uzročnosti (objektivna odgovornost), a bez vlastite krivnje (dok se odgovornost zbog kaznenog djela mora zasnivati na krivnji). ${ }^{44}$

42 Zahtjevi su u međusobnoj vezi u pravilu kad proizlaze iz bitno istog činjeničnog stanja i kad su usmjereni k ostvarenju bitno identičnog pravnog ili ekonomskog interesa. U pravilu je moguće prihvatiti samo jedan od njih jer se međusobno isključuju. - Triva, Dika, Građansko parnično procesno pravo, 422.

${ }_{43}$ U tom smislu Kunštek navodi kako se ovakvo rješenje može kritizirati jer postoje situacije u kojima neće postojati kaznenopravna odgovornost okrivljenika, ali postoji njegova građanskopravna odgovornost (npr. odgovornost za štetu od opasne stvari). Ono se u poredbenom pravu probija. Tako u Francuskoj u postupku pred Cour d’Assies može se prihatiti građanskopravni zahtjev oštećenog neovisno o oslobađajućoj presudi. - Kunštek, ,Actio civilis u kaznenom postupku - prijedlog novele“, 214.

44 V. Boris Vizner, Komentar Zakona o obveznim (obligacionim) odnosima (Zagreb 1978.), 630. i 639. - Po kriteriju objektivne odgovornosti traži se da oštećenik dokaže samo: štetnikovu štetnu radnju, štetu i uzročnu vezu između štetne radnje i nastale štete, dok se krivnja ne uzima u obzir. 
To bi za sud u kaznenom postupku bio svakako zahtjevniji zadatak jer bi prvenstveno morao odlučiti i obrazložiti zašto ne postoji kaznenopravna odgovornost okrivljenika te potom, odlučujući o imovinskopravnom zahtjevu, obrazložiti ne samo njegovu visinu, već i razloge za njegovo usvajanje primjenjujući norme građanskog prava koje uređuju građanskopravnu odgovornost za štetu. ${ }^{45} \mathrm{~S}$ druge strane, razlozi koji bi mogli govoriti u prilog uvođenju takve mogućnosti u naše kazneno zakonodavstvo mogli bi biti već spomenuti razlozi ekonomičnosti i izbjegavanja dvostrukog vođenja postupka.

\section{PODOBNOST SUDSKE ODLUKE ZA OVRHU}

Odluka suda donesena u kaznenom postupku kojom se u potpunosti ili djelomično usvaja imovinskopravni zahtjev mora biti valjana ovršna isprava, što znači da se na temelju takve odluke može odrediti ovrha. Takva odluka mora biti podobna za ovrhu pa u njoj moraju biti označeni vjerovnik i dužnik, te predmet, vrsta, opseg i vrijeme ispunjenja obveze (čl. 29. OZ-a) ${ }^{46}$ Iz izreke presude kojom se odlučuje o imovinskopravnom zahtjevu mora biti jasno tko je dužan naknaditi imovinskopravni zahtjev oštećeniku koji također mora biti određeno naznačen ${ }^{47}$ te na koji način. ${ }^{48}$

Ako ovršna isprava nije podobna za ovrhu, sud ce odbaciti prijedlog za ovrhu. Zbog toga se o pitanju podobnosti ovršne isprave za ovrhu mora voditi računa već prilikom postavljanja imovinskopravnog zahtjeva (a svakako prilikom donošenja odluke u kaznenom postupku). Ako sud propusti prilikom odlučivanja o imovinskopravnom zahtjevu naložiti okrivljeniku da isti isplati oštećeniku (već se npr. samo navede da se oštećenicima dosuđuje imovinskopravni zahtjev i u kojim iznosima), takva odluka ima deklaratorni, a ne kondemnatorni karakter te dovodi u konačnici do nemogućnosti ovrhe takve presude u tom dijelu. Zbog nedostatka

45 Građanskopravna odgovornost za štetu uvijek obuhvaća i obvezu naknade štete, ali obveza naknade štete može postojati iako nema odgovornosti za prouzročenu štetu, jer konkretnom uzrokovanju štete može nedostajati element protupravnosti. V. više u Vizner, Komentar Zakona o obveznim (obligacionim) odnosima, 620 .

46 Ovršni zakon, Narodne novine broj 112/12, 25/13, 93/14, 55/16, 73/17, 131/20 (dalje u tekstu: OZ).

47 Vrhovni sud Republike Hrvatske u odluci Kž 744/13 od 21. svibnja 2014: „Osim toga imovinskopravni zahtjev dosuđuje se „supružnicima $S$ “ što je neprecizno i nerazumljivo obzirom da imovinskopravni zahtjev može biti dosuđen ili fizičkoj ili pravnoj osobi, pojam supružnici je pravno neodređen."

48 Županijski sud u Zagrebu u odluci broj Kž-480/2017 od 11. srpnja 2017: „Ispitujući pobijanu presudu u smislu čl. 476. st. 1. t. 1. ZKP/08 povodom žalbi državnog odvjetnika i optuženika, ovaj sud je utvrdio da je prvostupanjski sud počinio bitnu povredu odredaba kaznenog postupka iz čl. 468. st. 1. t. 11. ZKP/08 jer je izreka presude nerazumljiva. Naime, izrekom pobijane presude prvostupanjski sud je na temelju čl. 158. st. 1 i 2. ZKP/08 oštećenom SDI dosudio imovinskopravni zahtjev spram I optužene i II optuženog u iznosu od 2400,00 kn. Takva izreka je u tom dijelu nerazumljiva, jer nije razvidno tko je dužan naknaditi imovinskopravni zahtjev oštećeniku i na koji način.“ 
kondemnacije izreka takve presude je nerazumljiva jer nije razvidno tko je dužan naknaditi imovinskopravni zahtjev. ${ }^{49}, 50$

Da bi ovršna isprava bila podobna za ovrhu, ona mora sadržavati jasnu i određenu oznaku tražbine i to u pogledu predmeta, vrste, opsega i vremena ispunjenja, a tražbina mora biti moguća, dopuštena, određena ili odrediva. ${ }^{51}$ Tako npr. kaznena presuda kojom je okrivljeniku izrečena bezuvjetna kazna zatvora uz primjenu uvjetne osude s dvostrukim uvjetom od kojih je jedan isplata tražbine oštećeniku, nije ovršna isprava za ovrhu te tražbine iz razloga što se ista odnosi samo na izricanje kaznenopravne sankcije, a ne na odgovarajuću odluku o imovinskopravnom zahtjevu. $^{52}$

Sud je vezan dispozicijama stranaka pa može odlučivati samo u granicama postavljenog zahtjeva. Kada oštećenik postavi samo imovinskopravni zahtjev u visini nastale štete, takav zahtjev u sebi ne uključuje postavljanje zahtjeva i u odnosu na kamate te sud nije ovlašten okrivljenika obvezati da uz određeni iznos štete isplati i pripadajuće kamate, iako smatra da mu iste pripadaju. Međutim, ako je oštećenik zatezne kamate zatražio, sud je, kad dosudi oštećeniku imovinskopravni zahtjev u novčanoj svoti, ovlašten odlučiti da je okrivljenik na taj iznos dužan platiti i zateznu kamatu od dana dospijeća do isplate u smislu čl. 29. ZOO-a. ${ }^{53,54}$

49 Županijski sud u Zagrebu u odluci broj. Kž-489/2017 od 11. srpnja 2017: „Kako je prvostupanjski sud u izreci pobijane presude naveo samo da se Z. banci d.d. dosuđuje postavljeni imovinskopravni zahtjev u navedenim iznosima, a nije naložio optuženicima ispunjenje obveze prema oštećeniku, odnosno naknadu imovinskopravnog zahtjeva, to je izreka pobijane presude u tom dijelu nerazumljiva zbog čega je počinjena i bitna povreda odredbama kaznenog postupka iz čl. 468 st. 1. t. 11 ZKP/08.“

50 Isto tako i Županijski sud u Zagrebu u odluci broj Kž-958/16, 15. studenog 2016. navodi da odluka o imovinskopravnom zahtjevu u okviru osuđujuće kaznene presude predstavlja ovršnu ispravu na temelju koje oštećenik ima pravo naplatiti svoje potraživanje. Slijedom toga, ta odluka mora biti jasna i iz nje nedvojbeno mora proizlaziti tko je dužan oštećeniku naknaditi štetu.

51 Činidba mora biti moguća, dopuštena i određena, odnosno odrediva (čl. 269. st. 2. ZOO-a).

52 Županijski sud u Varaždinu, Gž-17/10 od 5. veljače 2010: „Kaznena presuda kojom je optuženiku izrečena bezuvjetna jedinstvena kazna zatvora uz primjenu uvjetne osude sa dvostrukim uvjetom od kojih je jedan i isplata u određenom roku tražbine oštećenika, vezana je jedino uz izricanje kazneno pravne sankcije, te ista u smislu čl. 20. i 21. Ovršnog zakona ne predstavlja ovršnu ispravu."

53 Vrhovni sud Republike Hrvatske u odluci broj Kr-454/2002 od 27. studenog 2002. ističe: „Radi se zapravo o odluci suda donijetoj u tzv. adhezijskom postupku o stvarima koje spadaju primarno u domenu imovinskog prava. To znači da je sud dužan i ovlašten, kada u kaznenom postupku odlučuje o imovinskopravnom zahtjevu primijeniti odredbe imovinskog prava tj. odredbu čl. 29. st. 1. ZOO-a kojom je propisano da dužnik koji zakasni sa ispunjenjem novčane obveze duguje, osim glavnice i zateznu kamatu po stopi utvrđenoj zakonom.“

54 „Pri tome nije zadatak suda utvrđivanje točnog iznosa zakonske zatezne kamate, već samo tijeka kamate, jer apsolutni iznos ovisi o danu isplate koji je u trenutku donošenja presude nepoznat. Ako imovinskopravni zahtjev i dokazi u spisu pružaju dostatne podatke o visini zahtjeva i početku roka od kojeg teče zakonska zatezna kamata onda prvostupanjski sud treba dosuditi i kamate, a ne oštećenika u odnosu na zakonsku zateznu kamatu upućivati u parnicu." - Vrhovni sud Republike Hrvatske u odluci broj Kž- 573/14 od 9. lipnja 2015. 
Kada je više okrivljenika u kaznenom postupku, oni su solidarno odgovorni ${ }^{55}$ i ta solidarnost kod isplate dosuđenog imovinskopravnog zahtjeva mora biti naznačena u odluci (naravno, ako je oštećenik prijedlog podnio u odnosu na sve okrivljenike).

Prilikom odlučivanja o imovinskopravnim zahtjevima kazneni sud mora primijeniti pravila građanskog prava te se na ista treba i pozvati u presudi kojom odlučuje o osnovanosti imovinskopravnog zahtjeva na način da ga usvaja u cijelosti ili djelomično. ${ }^{56}$ Sud je u obrazloženju presude nakon provedenog kontradiktornog postupka dužan navesti razloge za svaku točku presude pa tako i za postavljeni imovinskopravni zahtjev.

Sud u kaznenom postupku ne bi mogao odlučivati o prigovoru prijeboja jer nije ovlašten utvrđivati postojanje bilo koje tražbine okrivljenika u kaznenom postupku.$^{57}$ Naime, kad tuženik prigovorom istakne zahtjev radi prebijanja u parnici, on time na specifičan način ostvaruje ona ista ovlaštenja koja ostvaruje isticanjem tužbenog zahtjeva.$^{58}$ Isticanjem prigovora radi prebijanja tuženik tvrdi da i on ima prema tužitelju svoj zahtjev koji navedenim prigovorom ističe, pa traži od suda da presudom izvrši prijeboj tih tražbina, te da nakon toga odbije tužiteljev zahtjev. ${ }^{59} \mathrm{To}$ znači da bi za odlučivanje o prijeboju sud morao utvrđivati postojanje tuženikove (odnosno u kaznenom postupku okrivljenikove) tražbine, a to u kaznenom postupku nije moguće (kao ni odbijanje zahtjeva oštećenika).

\section{SPECIFIČNA PITANJA KOD OVRHE ODLUKE O IMOVINSKOPRAVNOM ZAHTJEVU}

Odluka kaznenog suda u dijelu kojim je usvojen imovinskopravni zahtjev (u cijelosti ili djelomično) ovršava se po pravilima OZ-a. U ovršnom postupku oštećenik postaje ovrhovoditelj, a okrivljenik (osuđenik) ovršenik.

Načelo dispozicije određujuće je i u ovršnom postupku te je stoga ovrhovoditelj ovlašten odrediti opseg u kojemu će se ostvarivati njegova tražbina utvrđena u

55 Vrhovni sud Republike Hrvatske u odluci broj Kž 213/16 od 20. travnja 2016. navodi:

„Neovisno o podjeli otuđenog novca i predmeta, u odnosu na imovinskopravni zahtjev postoji solidarna odgovornost supočinitelja.“

56 Vrhovni sud Republike Hrvatske u Kž-916/08 od 12. svibnja 2010.: „Uz to, prvostupanjski sud će voditi računa i o tome da odluka o imovinskopravnom zahtjevu mora biti valjano obrazložena, a što znači da za moguće odbijanje ili djelomično odbijanje imovinskopravnog zahtjeva moraju biti dani razlozi (čl. 359. st. 4. ZKP-a) a što je u pobijanoj presudi sada izostalo jer nema razloga zašto je imovinskopravni zahtjev prihvaćen djelomično."

57 Isto i Dinka Šago, Marija Pleić, „Adhezijsko rješavanje imovinskopravnog zahtjeva u kaznenom postupku“, Zbornik Pravnog fakulteta Sveučilišta u Rijeci, br. 2. (Rijeka: Pravni fakultet Sveučilišta u Rijeci, 2012.) 972, https://hrcak.srce.hr/file.

58 Triva, Dika, Građansko parnično procesno pravo, 437.

59 Triva, Dika, Građansko parnično procesno pravo, 435. 
određenoj ovršnoj ispravi kao i predmet i sredstva ovrhe. On je to dužan učiniti već u samom prijedlogu za ovrhu. ${ }^{60}$

Sud je u ovršnom postupku vezan načelom strogog formalnog legaliteta slijedom čega prilikom donošenja rješenja o ovrsi nije ovlašten upuštati se u razmatranje konkretne materijalne zakonitosti i pravilnosti ovršne isprave, već je vezan rezultatima prethodnih postupaka iz kojih potječe ovršna isprava.$^{61}$ Kako se ovrha određuje samo na temelju ovršne ili vjerodostojne isprave (čl. 22. OZ-a) odlučno je da odluka kaznenog suda kojim se odlučuje o imovinskopravnom zahtjevu (na način da ga se usvaja u cijelosti ili djelomično) ima svojstvo ovršne isprave koja je podobna za ovrhu.

Daljnje postupanje suda određeno je odredbama OZ-a i to kako u pogledu određivanja tako i same provedbe ovrhe, pa bi sveobuhvatna analiza navedenog prelazila potrebe ovog rada i duboko zašla u domenu ovršnog prava. Stoga ćemo se u ovom radu ograničiti samo na razmatranje onih pitanja koja su izravno vezana uz imovinskopravni zahtjev odnosno ukazuju na specifičnost položaja oštećenika.

\subsection{Rok za dobrovoljno ispunjenje}

Svojstvo neke tražbine da se radi njezina ostvarenja može tražiti ovrha naziva se ovršivost. To svojstvo mogu imati samo one tražbine koje su utvrđene u ovršnoj ili vjerodostojnoj ispravi. ${ }^{62}$ Ako je ovršna isprava odluka suda, tražbina postaje ovršiva kad ta odluka stekne svojstvo ovršnosti, a to je u pravilu kada odluka postane pravomoćna iako je protekao rok za dobrovoljno ispunjenje (paricijski rok). Bit roka sastoji se u garanciji osuđenoj stranci da sve dok rok ne protekne protivnik neće biti ovlašten tražiti od suda njegovu ovrhu. ${ }^{63}$

U odluci kojom je naloženo ispunjenje tražbine na neko davanje ili činjenje u pravilu mora biti određen i rok za dobrovoljno ispunjenje. Prema odredbi čl. 29. st. 3. OZ-a, ako u takvoj odluci nije određen rok za dobrovoljno ispunjenje, taj rok određuje sud rješenjem o ovrsi.

ZKP/08 u svom čl. 181. st. 3. i 4. također uređuje postupanje kada u odluci nedostaje rok za dobrovoljno ispunjenje (paricijski rok) u kojem slučaju obveza mora biti ispunjena u roku od 15 dana od pravomoćnosti presude. Protekom tog roka presuda u navedenom dijelu postaje ovršna te je oštećenik ovlašten od suda koji je donio odluku tražiti izdavanje ovjerenog prijepisa odluke s naznakom da je ovršna ${ }^{64}$

60 Mihajlo Dika, Građansko ovršno pravo, I. knjiga, Opće građansko ovršno pravo (Zagreb: Narodne novine, 2007.), 132.

61 Dika, Građansko ovršno pravo, 54, a isto je izrijekom prihvaćeno i u sudskoj praksi što je razvidno i npr. iz odluke Županijskog suda u Splitu, Gž Ovr-818/2016. od 15. svibnja 2016.

62 Dika, Građansko ovršno pravo, 131.

63 Triva, Dika, Građansko parnično procesno pravo, 585.

64 Ranije važeći ZKP/97 takvu odredbu nije imao te je u sudskoj praksi bio izražen stav kako prilikom dosuđivanja imovinskopravnog zahtjeva u kaznenom postupku ne postoji paricijski rok u kojem je optuženik dužan naknaditi imovinskopravni zahtjev jer ga je dužan naknaditi po pravomoćnosti presude - odmah. - Županijski sud u Vukovaru, Kž-54/07 od 4. ožujka 2008. 


\subsection{Položaj oštećenika u ovršnom postupku i postupku stečaja potrošača}

Oštećenik kojem je dosuđen imovinskopravni zahtjev nema u ovršnom postupku poseban položaj niti prednost pri namirenju u odnosu na ostale tražbine i ovrhovoditelje. Okolnost da se radi o tražbini oštećenika relevantna je samo u slučaju kada se određuje koja su primanja izuzeta od ovrhe (čl. 172. st. 1. t. 7. OZa) pa tako naknada za rad osuđenika, koja je inače izuzeta od ovrhe, nije izuzeta za tražbine naknade štete prouzročene kaznenim djelom osuđenika.

Drugačija je situacija kod stečaja potrošača. Naime, prema Zakonu o stečaju potrošača ${ }^{65}$ (u daljnjem tekstu ZSP) cilj je poštenog potrošača osloboditi od obveza koje preostanu nakon unovčenja njegove imovine i raspodjele prikupljenih sredstava vjerovnicima (čl. 2. st. 1. ZSP-a). Potrošačem se smatra svaka fizička osoba koja sklapa pravni posao ili djeluje na tržištu izvan svoje trgovačke, poslovne, obrtničke ili profesionalne djelatnosti (čl. 4. ZSP-a), a postupak stečaja potrošača može se otvoriti samo ako je potrošač nesposoban za plaćanje. ${ }^{66}$

Nakon provedenog postupka i proteka razdoblja provjere, te ukoliko nisu ispunjene pretpostavke za donošenje rješenja o uskrati oslobođenja od preostalih obveza (čl. 75. ZSP-a) sud će donijeti rješenje o oslobođenju od preostalih obveza (čl. 76. ZSP-a). To oslobođenje ima pravni učinak u odnosu na sve vjerovnike, uključujući i vjerovnike koji tražbinu nisu prijavili u postupku stečaja potrošača, a na pokrenuti ovršni postupak djeluje tako da dovodi do njegove obustave.

Međutim, prema odredbi čl. 77. st. 1. t. 3. ZSP-a rješenjem o oslobođenju od preostalih obveza, potrošač se ne može osloboditi naknade štete nastale kaznenim djelom ili prekršajem. Isto se primjenjuje i kod jednostavnog stečaja potrošača. Stoga pokretanje stečaja potrošača, te jednostavnog stečaja potrošača nema nikakvog utjecaja na ovrhu koja se vodi radi namirenja tražbine naknade štete nastale kaznenim djelom koja može biti i predmet odluke o imovinskopravnom zahtjevu koja se prisilno provodi.

\subsection{Dispozitivna ovlaštenja oštećenika kao ovrhovoditelja}

U slučaju kada je kazneno djelo počinilo više okrivljenika, oni su solidarno odgovorni za štetu nastalu počinjenjem tog kaznenog djela. Solidarna obveza definira se kao takav obvezni odnos u kojemu je svaki od više suvjerovnika ovlašten zahtijevati ispunjenje cijele činidbe od bilo kojeg dužnika, a svaki od više sudužnika

65 Narodne novine broj 100/15 i 67/18. (u daljnjem tekstu: ZSP).

66 Čl. 5. st. 2. i 3. ZSP-a određuje da je nesposobnost za plaćanje - nemogućnost ispunjenja dospjelih novčanih obveza. Smatrat će se da je potrošač nesposoban za plaćanje ako najmanje 90 dana uzastopno ne može ispuniti jednu ili više dospjelih novčanih obveza u ukupnom iznosu većem od 30.000,00 kuna. 
obvezan je ispuniti cijelu činidbu, premda je sama činidba djeljiva. ${ }^{67}$ Oštećenik kao ovrhovoditelj ima pravo izbora protiv kojeg će od okrivljenika (osuđenika) kao ovršenika pokrenuti ovršni postupak i na kojoj njegovoj imovini.

Ako je činidba jednom ispunjena, namireni su svi vjerovnici i oslobođeni svi dužnici ${ }^{68}$ To znači da je za prestanak tražbine oštećenika dovoljno da je ispuni i samo jedan okrivljenik odnosno da se u odnosu na jednog uspješno provede ovršni postupak na način da se namiri oštećenik u cijelosti. Tražbina utvrđena u određenoj ovršnoj ispravi gubi svojstvo ovršivosti kad prestane postojati npr. ispunjenjem. Ako određena tražbina izgubi svojstvo ovršivosti, premda je utvrđena u ovršnoj ispravi, ovrha radi njezina ostvarenja nije dopuštena. ${ }^{69}$

\section{PODOBNOST ODLUKE O IMOVINSKOPRA VNOM ZAHTJEVU ZA PROVEDBU U DRUGOJ DRŽAVI ČLANICI EUROPSKE UNIJE}

\subsection{Uredba br. 1215/2012 Europskog parlamenta i vijeća od 12. prosinca 2012. godine o nadležnosti, priznavanju i izvršenju sudskih odluka u građanskim i trgovačkim stvarima (preinačena)}

Priznanje i ovrhu strane sudske odluke reguliraju pravila međunarodnog prava. U Republici Hrvatskoj navedenu materiju regulira Zakon o međunarodnom privatnom pravu $^{70}$ prema kojem se strana sudska odluka izjednačuje s odlukom suda Republike Hrvatske i ima pravni učinak u Republici Hrvatskoj samo ako je prizna sud Republike Hrvatske (čl. 66. st. 1. ZMPP-a).

Međutim, ako se radi o priznanju i ovrsi strane sudske odluke iz neke od država članica Europske unije (dalje u tekstu: EU), na to se pitanje primjenjuje Uredba br. 1215/2012 Europskog parlamenta i vijeća od 12. prosinca 2012. godine o nadležnosti, priznavanju i izvršenju sudskih odluka u građanskim i trgovačkim stvarima (preinačena) (dalje: Uredba Bruxelles Ibis).

To znači da se i pitanje priznanja i ovrhe sudske odluke koja je donesena u Republici Hrvatskoj, u nekoj drugoj državi članici, također rješava primjenom odredbi Uredbe Bruxelles Ibis ako je unutar njezina polja primjene. Načelni je stav da je sudsku odluku donesenu pred sudom države članice potrebno smatrati kao da je donesena pred sudom zamoljene države članice.

67 Vrhovni sud Republike Hrvatske, Kzz 35/11 od 28. veljače 2012:

„Osuđenom MB prvostupanjskom presudom naloženo je plaćanje imovinskopravnog zahtjeva solidarno s optuženim SY dakle, bilo je moguće zahtijevati od njega ispunjenje te obveze u cijelosti jer je osuđenik kao solidarni sudužnik bio dužan činidbu ispuniti u cijelosti, jednako kao i drugi sudužnik bez obzira što je ona djeljiva."

${ }_{68}$ Ivica Crnić, Odštetno pravo, drugo bitno izmijenjeno i dopunjeno izdanje (Zagreb: Zgombić i partneri d.o.o., 2008.), 158.

69 Dika, Građansko ovršno pravo, 132.

70 Narodne novine broj 101/2017. od 12. listopada 2017. (dalje u tekstu: ZMPP). 
Prema ustaljenoj praksi Suda EU-a iz teksta čl. 1. st. 1. Uredbe Bruxelles Ibis prema kojem se ista primjenjuje u građanskim stvarima bez obzira na vrstu suda, proizlazi da se Uredba Bruxelles Ibis primjenjuje i na odluke koje je u građanskim stvarima donio kazneni sud (tako u odluci broj C-172/91, Sonntag v Waidmann). Obrazlažući takvo tumačenje, Sud EU-a naveo je da, iako je pridružena kaznenom postupku, građanska tužba za naknadu štete zbog povrede koja je proizašla iz kaznenog djela, jest građanske naravi. Takva odluka ne bi potpadala pod domašaj Uredbe Bruxelles Ibis samo ako bi se štetnik smatrao javnim tijelom koje je djelovalo u vršenju javnih ovlasti (tako u odluci broj C-814/79, Netherlands v Rüffer).

Stoga se na pitanje priznanja i ovrhe (izvršenja) odluke o imovinskopravnom zahtjevu u državama članicama primjenjuje Uredba Bruxelles Ibis prema kojoj je načelno pravilo da se sudske odluke donesene u državi članici, koje su valjane ovršne isprave u toj državi, mogu ovršiti u drugoj državi članici bez zahtijevanja posebnog postupka u svrhu priznanja i bez zahtijevanja potvrde o izvršnosti i to na temelju primjerka sudske odluke koja ispunjava uvjete potrebne za utvrđivanje njezine vjerodostojnosti i Potvrde o sudskoj odluci u građanskim i trgovačkim stvarima koju izdaje sud porijekla na zahtjev zainteresirane stranke. Svrha je olakšati koliko je to moguće slobodu kretanja presuda predviđajući jednostavan i brz postupak izvršenja (tako u odluci broj C-414/92, Solo Kleinmotoren v Boch). Sudska odluka donesena u državi članici koja je izvršna u zamoljenoj državi članici izvršava se pod istim uvjetima kao i sudska odluka donesena u zamoljenoj državi članici. ${ }^{71}$

\subsection{Uredba (EZ) br. 805/2004 Europskog Parlamenta i Vijeća od 21. travnja 2004. godine o uvođenju europskog naloga za izvršenje za nesporne tražbine}

Kada se radi o određivanju ovrhe odluke o imovinskopravnom zahtjevu u drugim državama članicama EU-a, posebno je pitanje postoji li mogućnost primijeniti Uredbu (EZ) br. 805/2004 Europskog Parlamenta i Vijeća od 21. travnja 2004. godine o uvođenju europskog naloga za izvršenje za nesporne tražbine (dalje u tekstu: Uredba 805/2004). Navedena Uredba primjenjuje se u svim državama članicama EU-a osim u Danskoj, a njome se, uz određene uvjete, mogu izbjeći sve dotad potrebne posredne mjere u državi članici u kojoj se zahtijeva izvršenje za odluke donesene u drugoj državi članici, pod uvjetom da je dokazano da vrsta ili visina duga nije osporavana - tzv. nesporna tražbina (čl. 1. Uredbe 805/2004). Sudska odluka koja je potvrđena kao europski nalog za izvršenje u državama članicama podrijetla, priznaje se i izvršiva je u drugim državama članicama bez potrebe potvrđivanja izvršivosti i bez mogućnosti osporavanja njezina priznanja (čl. 5. Uredbe 805/2004).

71 Priznanje sudske odluke ili njezina ovrha odbija se samo na zahtjev osobe protiv koje se zahtijeva ovrha i to samo ako postoje razlozi iz čl. 45. i 46. Uredbe Bruxelles Ibis pri čemu sud države u kojoj se zahtijeva priznanje ne može nadzirati ispravnost pravne ili činjenične ocjene suda države u kojoj je donesena sudska odluka. 
Tražbina se smatra nespornom ako:

a) dužnik se izrijekom usuglasio s tražbinom priznajući je ili putem nagodbe koju je potvrdio sud ili je sklopljena pred sudom tijekom postupka,

b) dužnik nikada nije osporio tražbinu, u skladu s odgovarajućim procesnim pravilima, prema pravu države članice podrijetla, u tijeku sudskog postupka,

c) dužnik je izostao s ročišta ili nije bio zastupan na ročištu o predmetnoj tražbini, nakon što je prvotno osporio tražbinu tijekom sudskog postupka, pod uvjetom da takvo postupanje podrazumijeva prešutno priznavanje tražbine ili činjenica koje navodi vjerovnik u skladu s pravom države članice podrijetla,

d) dužnik izričito prihvaća tražbinu u autentičnoj (javnoj) ispravi.

Kada se radi o odlukama donesenima u parničnom postupku, isto bi se uglavnom odnosilo na presude zbog ogluhe, priznanja te sklopljene sudske nagodbe. Presuda kaznenog suda kojom je odlučeno o imovinskopravnom zahtjevu načelno bi ulazila u moguće područje primjene navedene Uredbe 805/2004. jer se radi o odluci koju je u građanskoj stvari donio kazneni sud, međutim, u kaznenom postupku nema mogućnosti donošenja presude zbog ogluhe, zbog izostanka, niti na temelju priznanja.

Imajući u vidu ranije uvjete navedene od a) do d) koji se moraju ispuniti da bi se tražbina smatrala nespornom pa tako i potpadala pod domašaj Uredbe 805/2004, kada se radi o odluci suda o imovinskopravnom zahtjevu treba voditi računa o uvodnim napomenama Uredbe 805/2004 (t. 5.) prema kojima bi pojam „,nesporna tražbina" trebao obuhvatiti sve situacije u kojima je vjerovnik, s obzirom na to da je utvrđeno da dužnik nije osporio ni vrstu niti visinu novčane tražbine, dobio bilo sudsku odluku protiv tog dužnika, bilo ovršnu ispravu u kojoj se traži izričit dužnikov pristanak, kao što je sudska nagodba ili javna isprava.

Stoga samo priznanje imovinskopravnog zahtjeva u kaznenom postupku uslijed kojeg ne postoji daljnja obveza suda izvoditi dokaze radi utvrđivanja visine tog zahtjeva, ne bi proizvodilo učinak nesporne tražbine. ${ }^{72}$

Nagodba se u pravnoj teoriji definira kao ugovor kojim stranke uređuju svoje građanskopravne odnose kojima mogu slobodno raspolagati, zaključen pred nadležnim sudom. ${ }^{73}$ U starijoj sudskoj praksi (VSH Rev 2220/87) bilo je navedeno da sudskom nagodbom treba smatrati i nagodbu sklopljenu u kaznenom postupku.

Najbliže sklapanju nagodbe u kaznenom postupku jest potpisivanje Izjave za donošenje presude na temelju sporazuma stranaka (čl. 360 st. 3. ZKP/08) koja je rezultat pregovora između državnog odvjetnika i okrivljenika. ${ }^{74} \mathrm{Ta}$ izjava između ostalog sadrži i očitovanje okrivljenika o podnesenom imovinskopravnom zahtjevu

72 Vrhovni sud Republike Hrvatske, Kž 626/14 od 20. siječnja 2015. godine:

„Kada je optuženik priznao počinjenje kaznenog djela a zatim slobodno se očitujući priznao i postavljeni imovinskopravni zahtjev, sud je u dijelu kako je presudio i mogao odlučiti samo na način da optuženika obaveže na plaćanje onog novčanog iznosa koji je od njega tražen i na što on priznajući ga pristaje bez potrebe za njegovu daljnju provjeru izvođenjem dokaza.“

73 Triva, Dika, Građansko parnično procesno pravo, 570.

74 Tako i Krapac u Kazneno procesno pravo, 95, navedeno naziva nagodbom. 
i njegov potpis. Očitovanje o postavljenom imovinskopravnom zahtjevu može biti priznanje ili poricanje takvog zahtjeva. Nakon potpisivanja izjave državni odvjetnik o tome obavještava oštećenika (čl. 360. st. 5. ZKP/08). Posebna suglasnost žrtve za sporazumijevanje potrebna je ako se radi o kaznenim djelima protiv života i tijela i protiv spolne slobode za koja je propisana kazna zatvora teža od pet godina.

Nakon što primi pisanu izjavu za donošenje presude na temelju sporazuma stranaka, vijeće će utvrditi jesu li stranke suglasne u odnosu na sadržaj izjave i to unijeti u zapisnik te potom odlučiti o potvrđivanju optužnice. Ako potvrdi optužnicu, vijeće će odlučiti o prihvaćanju izjave za donošenje presude na temelju sporazuma stranaka te će optuženiku izreći kaznu ili drugu mjeru kako je to navedeno u izjavi (čl. 361. ZKP/08). Ako izjava sadrži priznanje imovinskopravnog zahtjeva u određenom iznosu, presudom će se naložiti okrivljeniku da taj iznos isplati oštećeniku.

Imajući u vidu sve navedene okolnosti, smatramo kako bi se tako utvrđena tražbina mogla smatrati nespornom tražbinom te bi se presuda na temelju sporazuma stranaka donesena u kaznenom postupku u dijelu koji se odnosi na imovinskopravni zahtjev mogla u drugoj državi članici EU-a prisilno provoditi temeljem Uredbe 805/2004. Međutim, konačni sud o tome dat će praksa kroz postupke koji će u tom smislu eventualno biti pokrenuti u drugoj državi članici te posljedično i Sud EU-a ako mu bude postavljen odgovarajući zahtjev za prethodnu odluku.

\section{ZAKLJUČAK}

Relativno mali broj odredaba koje u kaznenom zakonodavstvu uređuju imovinskopravni zahtjev mogao bi pogrešno ukazivati da se ne radi o osobito značajnom ni složenom institutu. Unatoč navedenoj normativnoj manjkavosti, teorija i praksa ukazuju da se radi o institutu čiji je značaj daleko veći i koji zbog svoje specifičnosti, a to je da se radi o mješavini građanskog i kaznenog prava i postupka, zahvaća u brojne segmente oba postupka te široko u područje građanskog materijalnog prava.

Uz brojna pitanja koja se vezano uz imovinskopravni zahtjev postavljaju posebnu pažnju treba posvetiti upravo odlukama koje donosi sud tijekom tog postupka i to kako procesnim tako i meritornim.

Već je iz analize procesnih odluka koje bi se trebale donositi tijekom vođenja postupka razvidno da se u praksi ukazuje potreba za rješavanjem brojnih sporednih pitanja, a važeće zakonsko uređenje za te slučajeve ne propisuje (ili ne u dovoljnoj mjeri) način postupanja i ovlaštenja suda. Iako za određena pitanja postoje odredbe ZKP-a koje bi se mogle na odgovarajući način primijeniti to nije učinjeno nedvojbenim niti takvo zakonsko uređenje uzima u obzir specifičnost pitanja koja kod imovinskopravnog zahtjeva postoje zbog njegove građanskopravne naravi. Međutim, uz navedeno postoji i čitav niz procesnih pitanja koja kazneno zakonodavstvo ne predviđa niti regulira kao što je to slučaj nepostojanja procesnih pretpostavki za odlučivanje o imovinskopravnom zahtjevu, dvostruke litispendencije 
i res iudicate, ali i rješavanja univerzalne i singularne sukcesije tijekom postupka. Donošenje odgovarajućih procesnih odluka tijekom vođenja postupka, a osobito onih prema kojima bi imovinskopravni zahtjev trebalo odbaciti, potrebno je kako radi pravne sigurnosti tako i radi uvođenja reda u odnose među strankama. S obzirom na to da se u osnovi radi o parnici unutar kaznenog postupka, odgovarajuće odredbe o postupanju suda i navedenim procesnim odlukama sadržane su u ZPP-u. Stoga bi izložena sporna pitanja mogla biti riješena na najjednostavniji način propisivanjem supsidijarne primjene ZPP-a u situacijama kada sud u kaznenom postupku odlučuje o pojedinim procesnim pitanjima vezanim uz imovinskopravni zahtjev, koja nisu na odgovarajući način riješena odredbama ZKP/08.

Uz to, provedena analiza ukazuje kako sud nije ovlašten odbiti imovinskopravni zahtjev, a niti o njemu odlučivati ako nije donio osuđujuću presudu iako je izveo sve dokaze ne samo radi utvrđivanja kaznene odgovornosti, već i radi utvrđivanja imovinskopravnog zahtjeva. Stoga se može zaključiti da su prijedlozi prema kojima bi sud mogao odbiti imovinskopravni zahtjev (ali i istog usvojiti iako nije donio osuđujuću presudu) svrhoviti s aspekta ekonomičnosti postupka i izbjegavanja dvostrukog vođenja postupka. Na taj bi način oštećenik brže i jeftinije ostvario zaštitu svog povrijeđenog subjektivnog prava iako bi samom postupku trebao pristupiti znatno pažljivije i aktivnije. To bi posljedično znatno utjecalo i na smanjivanje broja parničnih postupaka koje prema sadašnjem zakonskom uređenju oštećenici pokreću kada ih kazneni sud na to uputi. Naravno, navedeno zahtijeva pažljivu razradu u kaznenom zakonodavstvu kako bi buduća zakonska regulacija predstavljala cjelovito rješenje uz odgovarajuću zaštitu procesnih prava svih sudionika postupka. To osobito kada bi se dalo ovlaštenje sudu odlučivati o imovinskopravnom zahtjevu i kada ne donese osuđujuću presudu, što bi i za sud bio svakako zahtjevniji zadatak jer bi prvenstveno morao odlučiti i obrazložiti zašto ne postoji kaznenopravna odgovornost okrivljenika te potom odlučujući o imovinskopravnom zahtjevu obrazložiti ne samo njegovu visinu, već i razloge za njegovo usvajanje primjenjujući norme građanskog prava koje uređuju građanskopravnu odgovornost za štetu.

Kako donošenje odluke nije samo sebi svrha već je to popravljanje povrijeđenog prava što upućuje i na moguću potrebu njezine prisilne provedbe, odluka kojom sud u kaznenom postupku odlučuje o imovinskopravnom zahtjevu mora biti podobna za ovrhu da bi bila valjana ovršna isprava. Iako iz formulacije odredbe čl. 158. ZKP/08 proizlazi da će sud imovinskopravni zahtjev "dosuditi", analiza dostupnih sudskih odluka ukazuje na to da su se odluke donosile i na način koji ih je činio nepodobnima za ovrhu jer bi im najčešće nedostajala kondemnacija, dakle, nalog okrivljeniku da određenu tražbinu ispuni oštećeniku. O navedenome se u praksi, iako to nije izrijekom navedeno već u pozitivnim odredbama kaznenog zakonodavstva, svakako treba voditi računa kako bi se izbjegle situacije da zbog nepodobnosti odluke ovrha bude nemoguća čime se onemogućava i ostvarenje osnovne svrhe cijelog instituta.

Zaključno možemo istaknuti kako provedena analiza pozitivnih kaznenopravnih odredbi koje u Republici Hrvatskoj reguliraju imovinskopravni zahtjev ukazuje na njihovu neusklađenost i manjkavost i u odnosu na pitanje odluka koje donosi i može 
donijeti sud u kaznenom postupku, što govori o tome da je navedeni institut i nadalje neopravdano zapostavljen iako bi otklanjanje navedenih nedostataka i daljnje unapređenje pojedinih rješenja otklonilo mogućnost neujednačenog tumačenja i primjene prava odnosno nejedinstvene prakse. To bi u konačnom bilo višestruko korisno i za pravosuđe, ali i za stranke.

\section{POPIS LITERATURE:}

1. Crnić, Ivica. Odštetno pravo, drugo bitno izmijenjeno i dopunjeno izdanje. Zagreb: Zgombić i partneri, 2008.

2. Dika, Mihajlo. Građansko ovršno pravo, I. knjiga, Opće građansko ovršno pravo. Zagreb: Narodne novine, 2007.

3. Dika, Mihajlo. Građansko parnično pravo, Parnične radnje, V knjiga. Zagreb: Narodne novine, 2008.

4. Dika, Mihajlo. Građansko parnično pravo, Tužba, VI. Knjiga. Zagreb: Narodne novine, 2009.

5. Krapac, Davor. Kazneno procesno pravo, Prva knjiga: Institucije. Zagreb: Narodne novine, 2015.

6. Kunštek, Eduard, „Actio civilis u kaznenom postupku - prijedlog novele“. Zbornik radova, Deset godina rada Zavoda za kaznene znanosti Mošćenice Pravnog fakulteta Sveučilišta u Rijeci (2008): 201-216, https://www.yumpu.com/it/document/ $\mathrm{read} / 18209553 /$ decennium-moztanicense.

7. Ovršni zakon, Narodne novine broj 112/12, 25/13, 93/14, 55/16, 73/17, 131/20.

8. Pavišić, Berislav i suradnici. Kazneno postupovno pravo. 3. izdanje. Rijeka: Pravni fakultet Sveučilišta u Rijeci, 2010.

9. Pavišić, Berislav. Komentar Zakona o kaznenom postupku. 5. izdanje. Rijeka: Žagar, 2005.

10. Sud Europske unije, Sudska praksa, https://curia.europa.eu/ (odluke C-172/91, C-814/79. i C-414/92.)

11. Šago, Dinka, Marija Pleić. „Adhezijsko rješavanje imovinskopravnog zahtjeva u kaznenom postupku“. Zbornik Pravnog fakulteta Sveučilišta u Rijeci, br. 2 (2012):967999, https://hrcak.srce.hr/file.

12. Triva, Siniša, Mihajlo Dika. Građansko parnično procesno pravo. Zagreb: Narodne novine, 2004.

13. Uredba br. 1215/2012 Europskog parlamenta i vijeća od 12. prosinca 2012. godine o nadležnosti, priznavanju i izvršenju sudskih odluka u građanskim i trgovačkim stvarima (preinačena).

14. Uredba (EZ) br. 805/2004 Europskog parlamenta i Vijeća od 21. travnja 2004. godine o uvođenju europskog naloga za izvršenje za nesporne tražbine.

15. Ustav Republike Hrvatske, Narodne novine broj 56/90, 135/97, 08/98, 113/00, $124 / 00,124 / 00,28 / 01,41 / 01,55 / 01,76 / 10,85 / 10,05 / 14$ 
16. Odluka Ustavnog suda Republike Hrvatske broj U-III-2509/2008 od 8. studenoga 2012., https://usud.hr/hr/praksa-ustavnog-suda.

17. Vedriš, Mladen, Petar Klarić. Građansko pravo, Opći dio, stvarno pravo, obvezno i nasljedno pravo. Zagreb: Narodne novine, 2003.

18. Vizner, Boris. Komentar Zakona o obveznim (obligacionim) odnosima. Zagreb: 1978.

19. Vrhovni sud Republike Hrvatske, Portal sudske prakse, https://sudskapraksa.csp.vsrh. hr/ (za sve odluke Vrhovnog suda Republike Hrvatske i županijskih sudova).

20. Zakon o kaznenom postupku, Narodne novine broj 152/08, 76/09, 80/11, 121/11, $143 / 12,56 / 13,145 / 13,152 / 14,70 / 17,126 / 19$.

21. Zakon o međunarodnom privatnom pravu, Narodne novine broj 101/2017.

22. Zakon o obveznim odnosima, Narodne novine broj 35/05, 41/08, 125/11, 78/15, $29 / 18$.

23. Zakon o parničnom postupku, Narodne novine broj 53/91, 91/92, 112/99, 88/01, 117/03, 88/05, 02/07, 84/08, 96/08, 123/08, 57/11, 148/11 (pročišćeni tekst), 25/13, $89 / 14$ i $70 / 19$.

24. Zakon o stečaju potrošača, Narodne novine broj 100/15 i 67/18.

25. Zakon o vlasništvu i drugim stvarnim pravima, Narodne novine broj: 91/96, 68/98, 137/99, 22/00, 73/00, 129/00, 114/01, 79/06, 141/06, 146/08, 38/09, 153/09, 143/12, $152 / 14$.

\section{DECISIONS OF THE COURT IN THE PROPERTY CLAIM PROCEDURE}

In this paper, the authors present an overview and an analysis of the existing criminal provisions governing the practice and procedure in the courts when deciding procedural issues or substantive matters concerning a civil claim. The specific nature of civil claims, which represent a combination of criminal and civil law and procedure, suggests that the courts, when deciding on such claims, should apply not only the provisions of criminal procedural law but also the provisions of civil procedural law in an appropriate manner. The paper therefore examines whether all procedural issues to be decided during the conduct of the proceedings are adequately regulated by the criminal legislation of the Republic of Croatia, including proposals for possible solutions. Furthermore, the paper points to the limited possibility of deciding on civil claims in light of the fact that the court has no authority whatsoever to reject or accept such claims in criminal proceedings unless it delivers a conviction. The authors also deal with certain specific issues which may arise in connection with civil claims in the course of the proceedings, the knowledge of which is necessary to ensure efficient and effective implementation of the decisions adopted by the court in criminal proceedings.

Key words: injured party, civil claim, adhesion procedure, damages, decisions, enforcement 